Vol. 2, No. 2, December 2021

SPEKTA

Jurnal Pengabdian Kepada Masyarakat : Teknologi dan Aplikasi

Journal homepage :

http://journal2.uad.ac.id/index.php/spekta

\title{
THE TRAINING TO UTILIZE SOCIAL MEDIA TO INCREASE PRODUCTIVITY OF LOCAL ARTISTS IN EAST JAKARTA DURING COVID- 19 PANDEMIC
}

\section{Dini Wahdiyati *, Winida Qusnul Khotimah}

Department of Communication Studies, Universitas Muhammadiyah Prof. Dr.Hamka, Indonesia

\begin{tabular}{l}
\hline ARTICLE INFO \\
\hline Recived : July, 2021 \\
Revised : November, 2021 \\
Accepted : December, 2021 \\
\hline
\end{tabular}

Keywords:

social media;

local artist;

covid 19.

\begin{abstract}
The COVID-19 pandemic affects many sectors of life including the world of art, particularly for local artists. They no longer have a stage to work on. The restriction policies during the pandemic Covid-19 limit their existence. As a result, the local artists in East Jakarta need a way to stay creative and productive. The lack of work performed has an impact on the lack of income they get. Thus, the community service team is looking for a solution to this problem by providing education about the use of social media. The method from this community service is carried out by providing knowledge about the types, features, and use of social media. Then, provide training to create content from the work of these local East Jakarta artists. From this training, East Jakarta local artists have started to understand the types, features, and use of social media. Besides, they also started to create content to share on their social media.
\end{abstract}

\section{INTRODUCTION}

The ongoing COVID-19 pandemic has many complex implications on several sectors of life. Many things have changed in the past year as Indonesia's pandemic has just started to come to an end. Economic difficulties are getting worse. Many businesses were forced to close and lose capital because there were no customers or visitors due to large-scale restrictions at the beginning of the last pandemic which impact is still being perceived today. Many offices have also been forced to reduce staff to be able to cover production costs and survive. Many also become victims of layoffs themselves and inevitably end up accepting their fate. In short, it is undeniable that everyone is affected by the COvid-19 pandemic. All fields of work also experienced it, especially among art workers who depend their life and existence on activities in the crowd in various events. They might become one among some parties who are the most affected by the pandemic. Not only unable to perform but also difficulty to fulfill the needs of daily life.

\footnotetext{
* Corresponding author.

E-mail address: winyninda@uhamka.ac.id

https://doi.org/10.12928/J.spekta.v2i2.4580
} 
Vol. 2, No. 2, December 2021

It has been well-written in our memory that Didi Kempot had been dedicated himself to collecting donations events for traditional Javanese artists to consider that this pandemic had completely destroyed their stage life. For sure, it is also encountered by all artists around the world. However, it is not wise to just keep on surrender to the existing situation. Charles Darwin's words seem very suitable as motivation in the context of the current situation. "It's not the strong that survives, but the good at adapting" that will be able to survive.

The stages of art now have to transform into virtual spaces. Many concerts and performing arts are no longer held in theaters or ballrooms since the Enforcement of Restrictions on Community Activities (PPKM) were imposed. However, many artists today choose to keep staying at the real stage mindset and not to switch to adapt to the virtual stage. However, the concerts are now possibly enjoyed without being overcrowded. It can now be enjoyed while relaxing at home with family for free or paid. Therefore, the artists can still exist and are productive even at home, by utilizing technology and various media platforms that exist today. In the end, this is how they apply the new normal in the context of their lives as local artists. In short, everyone is now used to doing activities through the media virtually.

Ironically, the real situation is not as great as we imagine. The lack of capacity and use of technology among local artists in the area of the former Condet cultural heritage, Kramatjati, Jakarta Timur Region adds to the series of sad stories of the pandemic that is even this year. Local artists, especially Betawi art performers, such as Pencak Silat, Palang Pintu, Cokek Dance, Lenong, Samrah Orchestra, and Rebana Ketimpring, who previously relied on responses from direct performance, along with large-scale social restrictions, became very limited in their work and creation. Unfortunately, they are unable to switch to new habits to continue performing and be productive during this pandemic because of the lack of insight into the use and mastery of the current state-ofthe-art, that is the social media platform.

These issues are also experienced by Preachers in Indonesia. During the pandemic, religious-based teaching cannot be arranged directly on the spot. It is due to the adjustments that need to be made to still be able to convey the message of religion and the existence of these preachers. Cahyono and Hassani (2019) found that YouTube is the most strategic new media for disseminating various information including da'wah. This research involves the YouTube accounts of preachers and teachers. For further study, training in the use of social media, especially YouTube, is much required to help the local artists able to share their work and live from through this platform.

As is known, the YouTube platform provides payment for those content creators whose viewers are at a minimum of 1000 (Cahyono \& Hassani, 2019). Not only displays audio, but Youtube also provides visuals that are more strategic for local artists to publish their work. As an advantage, the Youtube platform also provides no time limit for the duration of the video, an accurate security system, as well as is a profitable business medium (Faiqah \& Nadjib, 2016).

Not limited to that, research on the study on the use of social media in local arts has been carried out by Santi Susanti (2019). The research, entitled Preserving Local Wisdom Through Social Media, aims to determine the use of social media in socializing Sundanese local wisdom in accessories craft works through mass media. The socialization was carried out by a craft artist, Anthony Sutrisno through accessories that were made based on the philosophy of Sundanese local wisdom; cageur, bageur, bener, pinter, singer. Positive responses from the viewers appear in the provided comments column. He hopes 
Vol. 2, No. 2, December 2021

that the communication he does through social media can at least increase the knowledge of netizens about the need to preserve nature so that nature can give positive replies to humans. This study shows that there is a need for socialization to the public regarding the use of social media in the world of art.

The training with the theme of using social media has previously existed. As found, the training entitled "Training to create educational content for social media for students of SMP Muhammadiyah 4 Cipondoh Tangerang during the Covid-19 pandemic" (Khotimah, Agustini, Supriyadi, 2020). This training was conducted for junior high school students to use social media as a means of education. This training has a different location, object, and purpose from training on the use of social media among artists. In short, this social media training for local artists is aimed at increasing their productivity and work existence.

The results of the initial observations conducted by the community service team come to initiate an inventory of several issues related to the use of media. Our partners from Rumah Kreatif Condet (RKC) and Sanggar Pelangi both acknowledge the lack of concern for the use of media to support artwork among local artists in the Condet area. In addition, they also find it difficult to conduct training in the use of media because of the absence of qualified resources.

Condet, as a former Betawi cultural heritage area does indeed have many local artists who are concerned with Betawi culture. Our partners declared some Betawi studios in Condet area as seen in Table 1.

Tabel 1. The data of art studios in Condet area

\begin{tabular}{|c|c|}
\hline The Art Studio & Location \\
\hline Sanggar Betawi Firman Muntaco & $\begin{array}{l}\text { Jalan AMD 28, No.98 RT 06, RW 05, } \\
\text { Belakambang }\end{array}$ \\
\hline Sanggar Pelangi & $\begin{array}{l}\text { Jalan AMD 28, No.56, RT 06/RW 05, } \\
\text { Balekambang }\end{array}$ \\
\hline Sanggar Virtual RKC & $\begin{array}{l}\text { Jalan Munggang No.9, Gang Rawa Elok, } \\
\text { Balekambang }\end{array}$ \\
\hline Sanggar Betawi & $\begin{array}{l}\text { Jalan Cililitan Kecil II, No. 11, RT14/RW 7, } \\
\text { Cililitan }\end{array}$ \\
\hline Sanggar Seni Betawi & Jalan Lebak Para RT 08/RW 02 No.45, \\
\hline Cijantung/Putra Maya & Cijantung, Ps Rebo. \\
\hline Sanggar Silat Persatuan Haji & Batu Ampar, Condet \\
\hline Ridwan & \\
\hline Sanggar Ronce Melati & Jalan Damiri, Batu Ampar, Condet \\
\hline Sanggar Padepokan Betawi Condet & Balekambang, Condet \\
\hline Jelita Sanggar Tari Betawi & Jalan Munggang, Condet Balekambang \\
\hline Sanggar Widya Pelangi & Condet \\
\hline
\end{tabular}

Furtherly, our partner explained that not many Betawi studios are actually registered. There are some studios and other local Betawi Culture activists who are not registered. However, both of our partners studios have been officially registered with the DKI Jakarta Sub-Department of Culture (dinaskekulturan.jakarta.go.id). 
Vol. 2, No. 2, December 2021

\section{METHOD}

There were three stages implemented during this training process. These stages include, (1) field surveys, (2) counseling, (3) training (Khotimah, 2020). The method of implementing this training is described in the Figure 1.

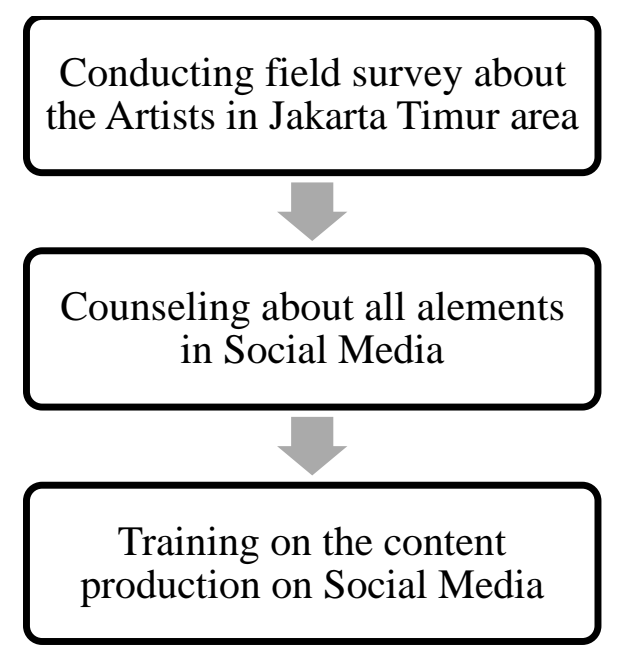

Figure 1. The training implementation stages

The field survey was carried out by the community service team to find out the real circumstances met by local artists in the East Jakarta area who were affected by the Covid19 Pandemic. After conducting a field survey, the community service team mapped the problem and conceptualized the type of training needed by local artists. The second stage is providing counseling. This stage is carried out online through the Google Meet platform. Counseling is constrained by the government's regulations for the Enforcement of Community Activity Restrictions (PPKM), so it is only possible to do online meetings. At this stage, the community service team explains the types, features, and use of social media. Then, followed by a discussion as well as question and answer sessions. Furthermore, the activities continued at the training stage. The training includes monological methods, discussions, and practices (Riyanto, 2018). The training activities include making videos and uploading them to social media accounts by the art studio. The following is a schedule of community service activities according Table 2.

Table 2. The training schedule

\begin{tabular}{|c|c|c|c|}
\hline Day & Time & Activity & Speakers \\
\hline \multirow[t]{2}{*}{1} & $09.00-10.30$ & $\begin{array}{l}\text { Topic: The opportunities \& use } \\
\text { of digital media for local art } \\
\text { publication }\end{array}$ & $\begin{array}{l}\text { Community service } \\
\text { team }\end{array}$ \\
\hline & $11.00-12.00$ & $\begin{array}{l}\text { Topic: Characteristics and } \\
\text { introduction of various digital } \\
\text { media platforms (Instagram, } \\
\text { YouTube, TikTok, Facebook) }\end{array}$ & $\begin{array}{l}\text { Community service } \\
\text { team }\end{array}$ \\
\hline
\end{tabular}


Vol. 2, No. 2, December 2021

\begin{tabular}{|c|c|c|c|}
\hline \multirow[t]{3}{*}{2} & $13.00-14.00$ & Advanced topic and discussion & $\begin{array}{l}\text { Community service } \\
\text { team \& local artists }\end{array}$ \\
\hline & 09.00-12.00 & $\begin{array}{l}\text { Brainstorming and content } \\
\text { creation planning }\end{array}$ & $\begin{array}{l}\text { Community service } \\
\text { team \& local artists }\end{array}$ \\
\hline & $13.00-15.30$ & Production and evaluation & $\begin{array}{l}\text { Community service } \\
\text { team \& local artists }\end{array}$ \\
\hline
\end{tabular}

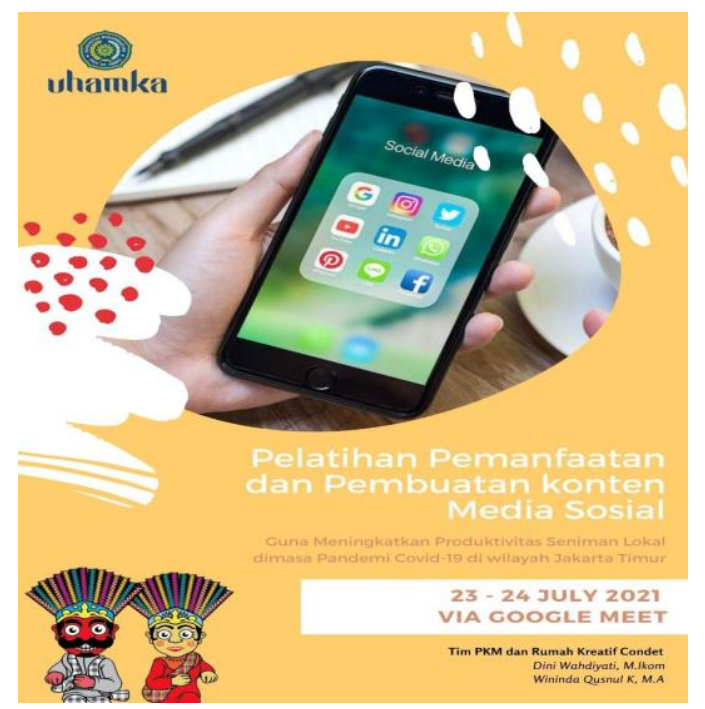

Figure 2. Flayer for participant

\section{RESULTS AND DISCUSSION}

Referring to the background and methods of the program implementation, some of the findings in this activity went smoothly as planned. The results of community service activities are divided into several indicators, namely the importance of this training, the outcomes of the training, as well as driving and inhibiting factors in this community service activity. The detail description is as listed as follows:

\section{A. The need of social media literacy}

This training employed a counseling method with monologue and discussion. To afford literacy about social media, the community service team explained what types, features, and how to use social media. There are several categories of social media, namely social networking, blogs, microblogging, media sharing, social bookmarking, and wikis (Nasrullah, 2015: 39). In this training, the service team used two types of social media. First, social networking such as Instagram and Facebook. Second, sharing media, namely YouTube and TikTok.

Instagram has several main menus such as home page, comments, explore, profile, and news feed (Atmoko, 2012: 28). This menu or feature is also added to an Instagram story referring to the Snapchat social media concept of its time. Besides, there is also the Reels feature which refers to TikTok videography. With the Reels feature, users can upload videos that they can easily edit themselves. The various conveniences in using Instagram are also supported by its ability as means of business and advertising. So, this is what needs to be educated to the local artists regarding the use of Instagram.

The next social networking is Facebook. Facebook has several benefits related to interactive media, education, and even market places. This benefit is supported by several features such as user profiles, status (links, photos, videos, questions, text), account settings, Facebook live, Facebook 360, group videos, advertising, and messenger day 
Vol. 2, No. 2, December 2021

(Patria et al, 2011). The features of Facebook have been well-developed and much different from the beginning of its coming. Besides, its function has also much changed over time. Many use Facebook as a business medium with this advertising feature. This advantage is presented by the service team to the artists, to understand what features can be used to support the productivity and sustainability of their work and income. Artists need a lot of support and education related to the use of this social networking. Previously, they only used Instagram and Facebook as a medium of interaction. However, this social networking can be a means of existence and survival of local artists.

The next platform is media sharing which allows users to store and share audio and video. Youtube is the most popular social media for sharing videos. The common term for those who make video or content for Youtube is known as YouTubers or content creators. The term is accompanied by fame and income earned by monetization. Youtube is the largest video service provider today and also for free uploads. The features of YouTube are YouTube editor, YouTube Cisco, YouTube Live, and YouTube charts (Mangole, 2017). Youtube is also a social media that will reward users whose videos reach 1000 views valued at 1 USD.

Besides, TikTok becomes the next social media platform. It is more of a content distribution platform because it emphasizes the consistency of content creation from its users. Unlike other social media (Republika.co.id accessed 27/7/21, 6:20). Therefore, in this counseling, the speakers from the community service team conveyed about live features, videos, filter effects, and voice changers. This counseling showed what we can do and use. This is related to the ability of videography in TikTok, entertainment, personal branding, as well as business. In this activity, counseling was carried out through a Google Meet which was attended by 12 artists from three different arts' studios. They are all from Sanggar Pelangi, RKC, and Sanggar Silat Babe Ridwan. The following are the outreach activities carried out:

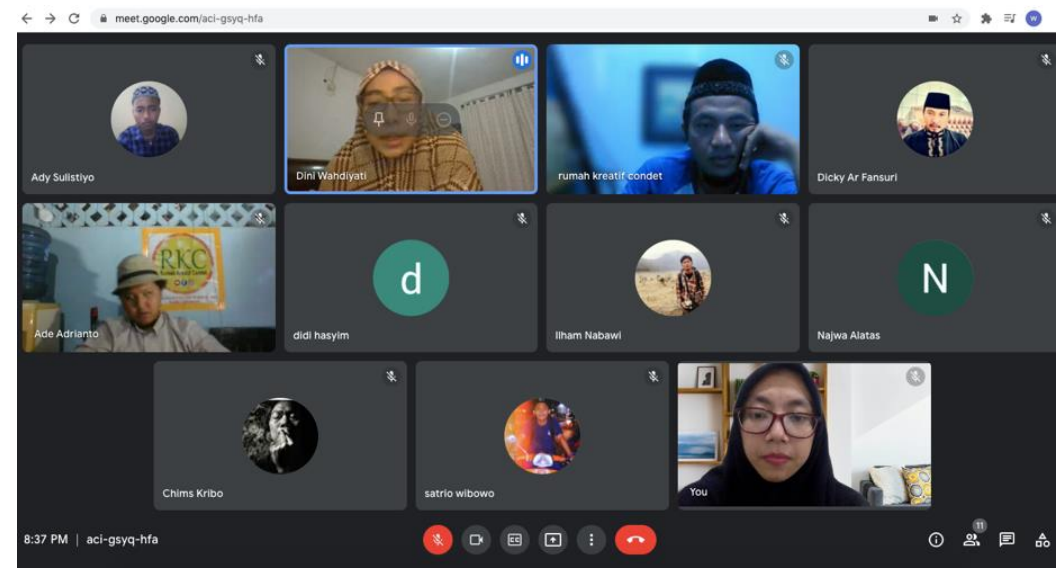

Figure 2. Counseling stage: The counseling of utilizing social media through Google Meet

During the online counseling process, the presenters conveyed how to understand the features and use social media. It was to help raise the existence of these local artists. It was then followed by a discussion related to what problems they face in the use of social media. In detail, some of the obstacles the artists encountered in utilizing social media were:

1. Lack of literacy on the social media features and utilization

2. Local artists don't understand uploading content via Youtube 
Vol. 2, No. 2, December 2021

3. Local artists need assistance in content creation and publication through appropriate social media.

\section{B. Raising the Productivity of Local Artists}

The Covid-19 pandemic that has occurred for more than a year has brought various impacts. The continuation of government policies such as Large-Scale Social Restrictions (PSBB) to the Implementation of Community Activity Restrictions (PPKM) has an impact on the capacity or sustainability of SMEs (Mustika, Tiara, and Khotimah, 2020). The meant SMEs are related to the activities of local artists. These local artists usually work offline. They need a stage to present their work in exhibitions and in crowds. However, those related government policies to prevent the spread of the pandemic restricted their movement to conduct offline exhibitions. The survival of the artists during this pandemic has certainly become a crisis which is a direct impact of some of these government policies. In addition, the productivity of artists will be constrained which affects no income of these local artists. Even worse, some were found to have to sell their musical instruments and other artistic instruments to increase their income and survive. One among some main obstacles faced by these local artists is related to the use of social media. It becomes the prominent reason for this training in order to help them work and earn income even without holding exhibitions or live art performances. The presence of the internet and technological-based social media make anyone able to publish or promote their works easily, quickly, and cheaply (Hendro, 2021).

Not only converting works into digital media but the ability to use social media by local artists will also certainly help the productivity and existence of their works. If they don't work, it's likely that local artists will no longer be known. Local culture and diversity will also be increasingly eroded by the lack of digital literacy or the adaptation of artists to the digital world. This existence is very much needed to preserve the local arts and culture as proof of existing performance (Diansyah, 2011).

The efforts to increase the productivity of artists through the use of social media became the main goal of the community service program. Therefore, to see how the results of this training, the team set the achievement indicators or criteria which are shown in the table 3.

Table 3. The achievement indicators

\begin{tabular}{llll} 
No & \multicolumn{1}{c}{ Indicators } & \multicolumn{1}{c}{ Pre-training } & \multicolumn{2}{c}{ Post-training } \\
\hline 1 & $\begin{array}{l}\text { The understanding } \\
\text { towards social media } \\
\text { types and features }\end{array}$ & $\begin{array}{l}\text { Some artists don't get } \\
\text { enough knowledge } \\
\text { about features of social } \\
\text { media. }\end{array}$ & $\begin{array}{l}\text { Artists who have } \\
\text { attended training can } \\
\text { find out how to use the } \\
\text { features of existing } \\
\text { social media. }\end{array}$ \\
$\begin{array}{l}\text { The understanding } \\
\text { towards the use of social } \\
\text { media }\end{array}$ & $\begin{array}{l}\text { Some artists only use } \\
\text { one single social media } \\
\text { to share their work }\end{array}$ & $\begin{array}{l}\text { Gain knowledge about } \\
\text { monetization on each } \\
\text { social media platform, } \\
\text { the advantages of each } \\
\text { social media and their } \\
\text { difference. }\end{array}$ \\
\hline
\end{tabular}


Vol. 2, No. 2, December 2021

3 The ability to create art Have not created art Utilization of social works through the content uploaded in media becomes more existing social media. various social media effective, not only using platforms. one social media to share their work, but also some others.

Some of the local artists who attended the training have already been familiar with social media such as Facebook, Instagram, Youtube, Twitter, and even TikTok. However, knowledge of the features of social media is still very minimal. The use of social media is still at the level of interaction and accessing information only. The use of social media today is not only at the level of mutual interaction, but also collaboration. Besides, it is also a means of business or promotion. One of them is Instagram that has various conveniences in sharing messages. Instagram also provides a feature of sharing photos and even videos (Puspitarini and Nuraeni, 2019). This convenience is also supported by the benefits that users get if their account gets a lot of viewers or engagement. Thus, this training also focuses on creating Instagram accounts. In detail, this training produces the following outputs in the figure 3 .

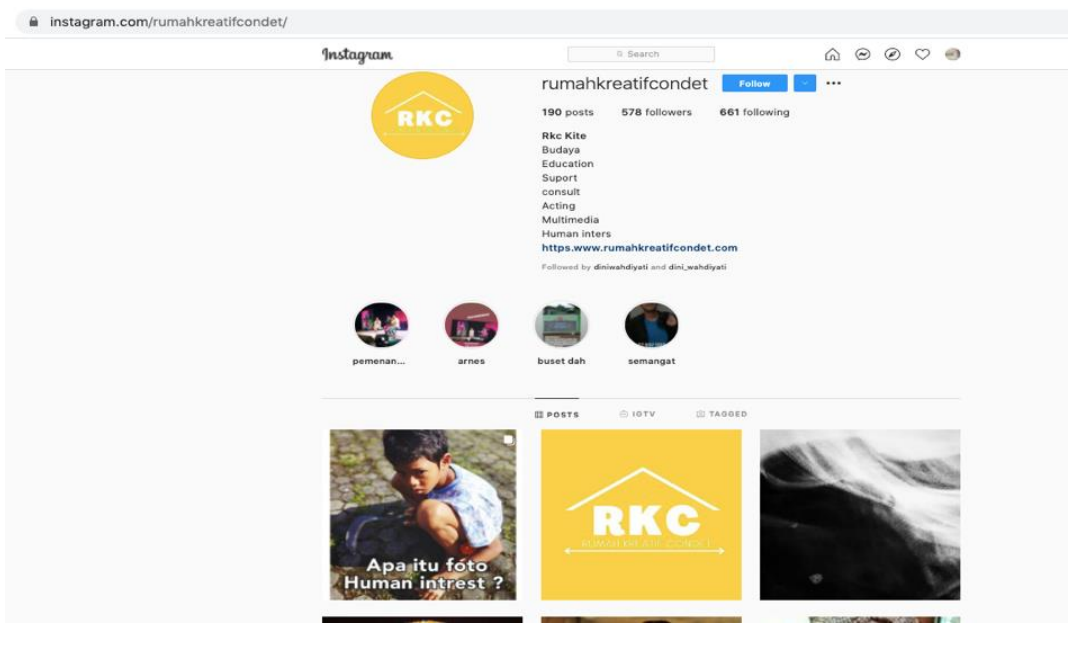

Figure 3. Instagram Account of One of the Art Communities Participating in Training

The Instagram account shown in Figure 3 belongs to one of the communities that participated in the training. It is also the main partner in this community service program. Condet Creative House (RKC) is a partnership that owns and shares its artistic activities through Instagram. Instagram is the social media chosen because of the increasing number of Instagram users in Indonesia (Puspitarini and Nuraeni, 2019). Besides Instagram, some of the practices carried out in this training are creating and uploading videos through a YouTube account. Furthermore, it might be observed through the following Figure 4. 
Vol. 2, No. 2, December 2021

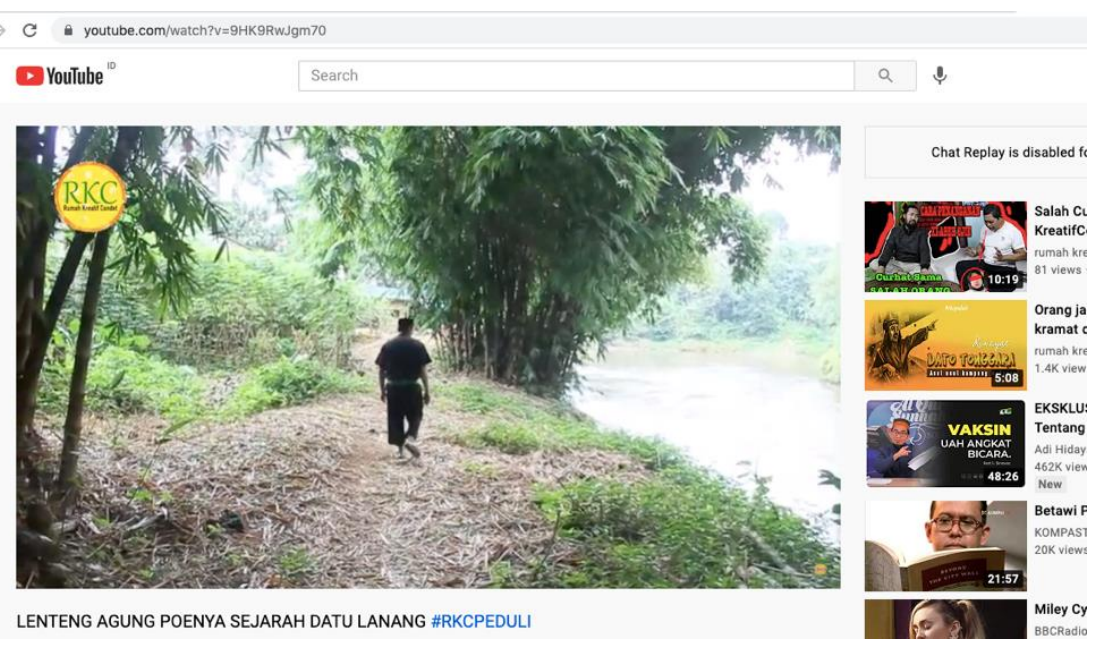

Figure 4. One of the Content Uploaded on YouTube

The community service team has provided training regarding the use of social media to publish artworks from local artists. This training offers outputs in the form of content uploaded on Instagram and YouTube.

\section{Obstacles and supporting factors}

Some of the obstacles encountered in this training are:

1. The training on creating creative content by utilizing social media by local artists was originally planned to be carried out on the spot. However, along with the surge in the number of Covid 19 cases and the government implementing an emergency PPKM (Enforcement of Community Activity Restrictions), the training design had to be changed online. This condition created coordination problems for PKM Team.

2. Online training becomes less optimal due to the lack of digital application use by the training participants.

3. To facilitate communication and the process of PKM activities, the internet is crucial. The limited internet of participants must also be provided by the PKM team.

4. The fewer participants involved because the training design had to be changed and conducted online had implications for several participants. They quit due to their lack of mastery of digital literacy.

Some of the supporting factors for this community service program might be resumed as the following points:

1. Seeing the urgency of the needs of the participants, this program was positively then responded. Furthermore, the community service team was also asked to accommodate similar projects more intensively.

2. Training related to sustainable use and digital literacy is needed by local artists to be more proficient in using digital media as a means of producing content, expanding publications, and seizing business opportunities so that they can be more productive.

3. Urgent training topics to hold again more intensively related to effective content creation strategies. The introduction of features of various relevant 
Vol. 2, No. 2, December 2021

digital media platforms utilized by artists are also important related to strengthening the concept of digital media content in artworks.

\section{CONCLUSION}

This training program succeeded in providing the new required abilities for local artists, especially the use of social media as a medium for publishing artwork. They become more aware of the features that exist on social media, the use of social media, and how monetization applies on social media. In addition, local artists are also equipped with the capacity to create content. The real output of this training is in the form of photos and videos as the content they created to be then converted into digital space.

This training on digital literacy is a necessity in the current industry 4.0 era, including for those local artists. The ability to use social media is a needed skill to survive during the Covid-19 pandemic. In the future, similar training in the use of digital media needs to be more comprehensively developed, especially for onsite or direct training. It is so that the local artists who have low digital literacy can be more proficient in using social media. The drawback of this training is that there are still few trainees involved, even though these artists need this ability for the existence of their local art groups or studios.

\section{ACKNOWLEDGEMENT}

In this community service program, the team would like to express their gratitude to all partners who were willing to help introduce art studios in Jakarta Timur Region. The gratitude was also expressed to Rumah Kreatif Condet (RKC), for being a partner that facilitated this community service, especially during this pandemic situation.

\section{REFERENCES}

Atmoko, B. D. (2012). Instagram Handbook. Jakarta: Media Kita.

Cahyono, G., \& Hassani, N. (2019). Youtube Seni Komunikasi Dakwah Dan Media Pembelajaran. Jurnal AL HIKMAH: Jurnal Dakwah, 13.

Diansyah, A. (2011). Eksistensi Damang Sebagai Hakim Perdamaian Adat Pada Masyarakat Suku Dayak di Palangkaraya. Universitas Udayana

Faiqah. F, Nadjib. M, Amir. A.S. (2016). YouTube Sebagai Sarana Komunikasi Bagi Komunitas Makassarvidgram. Jurnal Komunikasi KAREBA. Vol.5 No.2 Juli Desember.

Hendro, F., Setiawan, T., \& Setiawati, D. (2021). Mempertahankan Eksistensi Tradisi Tungguk Tembakau melalui Media Sosial. Jurnal Ilmu Komunikasi, 19(1), 78-92.

Khotimah, W. Q., Agustini, V. D., \& Supriyadi, A. (2020). Pelatihan Membuat Konten Edukatif untuk Media Sosial bagi Siswa SMP Muhammadiyah 4 Cipondoh Tangerang di Masa Pandemi Covid-19. Journal of Servite, 2(2), 49-55.

Mangole, K. D. B., Himpong, M., \& Kalesaran, E. R. (2017). Pemanfaatan Youtube Dalam Meningkatkan Pengetahuan Masyarakat Di Desa Paslaten Kecamatan Remboken Minahasa. Acta Diurna Komunikasi, 6(4).

Mustika, S., Tiara, A., \& Khotimah, W. Q. (2020). Pelatihan Meningkatkan Kapasitas UMKM Mitra Masjid Dalam Menghadapi Pandemi Covid-19. In Prosiding Seminar Nasional Program Pengabdian Masyarakat.

Nasrullah, R. (2015). Media Sosial. Bandung: Simbiosa Rekatama Media. 
Vol. 2, No. 2, December 2021

Patria, L., \& Yulianto, K. (2011). Pemanfaatan Facebook untuk Menunjang Kegiatan Belajar Mengajar Online Secara Mandiri. In Prosiding Seminar Nasional FMIPA $U T$.

Puspitarini, D. S., \& Nuraeni, R. (2019). Pemanfaatan Media Sosial Sebagai Media Promosi. Jurnal Common, 3(1), 71-80.

Riyanto, A. D., \& Noeris, M. F. (2018). Pelatihan Pemanfaatan Media Sosial sebagai Media Promosi Online untuk Pelaku UMKM di Cilacap. J-ABDIPAMAS (Jurnal Pengabdian Kepada Masyarakat), 2(2), 53-58.

Susanti, S., \& Sukaesih, S. (2019). Melestarikan Kearifan Lokal Melalui Media Sosial. Aksara Public, 3(2), 158-166

https://dinaskebudayaan.jakarta.go.id/disbuddki/ diakses 15 Apri 2020

https://www.republika.co.id/berita/gaya-hidup/trend/19/10/14/pzciyc328-tiktok-bukanmedia-sosial-lho/ diakses 27 Juli 2021. 
SPEKTA

Jurnal Pengabdian Kepada Masyarakat : Teknologi dan Aplikasi

Vol. 2, No. 2, December 2021

This page is intentionally left blank. 